\title{
Spatial modeling of erosion hotspots using GIS-RUSLE interface in Omo-Gibe river basin, Southern Ethiopia: implication for soil and water conservation planning
}

\author{
Rediet Girma ${ }^{1 *}$ (D) and Eshetu Gebre ${ }^{2}$
}

\begin{abstract}
Soil degradation due to soil erosion is one of the major environmental threats in developing countries. In resource limited conditions, computing the spatial distribution of soil erosion risk has become an essential and practical mechanism to implement soil conservation measures. This study aimed to assess the spatial distribution of soil loss in Omo-Gibe river basin using the integration of computer-based RUSLE and ArcGIS 10.7.1 to identify areas that require erosion prevention priority. Once raster layer of the input parameters was created, overlay analysis was carried to assess the spatial distribution of soil loss. The estimated annual soil loss varies from $0-279 \mathrm{t} \mathrm{ha}^{-1} \mathrm{yr}^{-1}$ with a mean annual soil loss of $69 \mathrm{t} \mathrm{ha}^{-1} \mathrm{yr}^{-1}$. The empirical analysis also confirmed that the basin losses a total of about $89.6 \mathrm{Mt}$ of soil annually. Out of the total area; $7 \%$ was in very sever class, $4.8 \%$ was found in the sever and $8.7 \%$ was categorized in very high range. The remaining area were ranging from low to high erosion risk class. The influence of the combined LS factor for soil loss is significant. It was observed that small area of the Omo-Gibe basin contributed for the significant amount of soil loss. The finding of this study is in a good agreement with previous studies. Compared to the country permissible soil loss rate, $26 \%$ of the entire basin significantly exceeds the country threshold value (TSL $=18 \mathrm{t}$ $\left.\mathrm{ha}^{-1} \mathrm{yr}^{-1}\right)$. As a result, precedence and immediate attention should be given to those erosion prone areas. The study output could deliver watershed management experts and policy makers for better management implementation and resource allocation based on the local context.
\end{abstract}

Keywords: Soil erosion, RUSLE, Severity class, Spatial modeling, Soil conservation, Omo-Gibe

\section{Background}

The world-wide adverse influence of soil erosion has been considered as the most critical issues resulting in both on-site and offsite effects (Zhou et al. 2014; Aiello et al. 2015; Zhou and Wu, 2008). In developing countries like Ethiopia, soil erosion by water and the resulting land degradation (Alexandridis et al. 2015; Panditharathne et al. 2019) are an alarming problem that led to a significant

\footnotetext{
*Correspondence: red8.girma@gmail.com

${ }^{1}$ Department of Sustainable Landscape Development, Institute for Geosciences and Geography, Martin Luther University HalleWittenberg, Halle, Germany

Full list of author information is available at the end of the article
}

economic crisis and negative environmental threat (Shiferaw et al. 2009; Fazzini et al. 2015). Several scholars confirmed that anthropogenic factors (Balabathina et al. 2019) mainly rapid population growth, cultivation on steep slopes and rapid land use changes due to intensive agricultural practices aggravate soil erosion in Ethiopia (Abate, 2011; Tesfaye, 2015). Soil erosion and nutrient depletion is one of the major bottlenecks affecting the sustainability of agricultural production (Adugna et al. 2013; Wolka et al. 2015; Beshir and Awdenegest, 2015).

Modeling the spatial distribution of erosion risk can be used as predictive tools (Popp et al. 2000) and has become essential for land managers and policy makers to 
implement sustainable intervention measures (Fernandez et al. 2003; Lu et al. 2004). Quantitative estimation of soil loss to identify erosion prone areas provides useful information to implement suitable intervention measures (Wischmeier and Smith 1978; Shi et al. 2004; Haregeweyn et al. 2013). In this regard, the integration of Revised Universal Soil Loss Equation (RUSLE) with geographic information system (GIS) provides a rather simple and yet comprehensive erosion quantification framework (Gelagay and Minale, 2016). In 2018, Gashaw (2018) and his colleagues has been used the RUSLE empirical erosion model as it is clear and relatively requires simple computational input data.

The advancement in GIS and remote sensing technologies assists to attain the RUSLE input parameters at limited costs and with reasonable accuracies (Phinzi and Ngetar 2019). The RUSLE model is the most widely-used model for erosion assessment and conservation planning (Meshesha et al. 2012 and Wolka et al. 2015). The model has been tested in different part of Ethiopia by modifying some of the factors and found valid (Meshesha et al. 2012; Belayneh et al. 2019). In this background, this assesses the spatial distribution of soil loss and identify areas that require prior soil conservation measures using RUSLE integrated with GIS at Omo-Gibe river basin.

\section{Materials and methods \\ Study area description}

Omo-Gibe River Basin is situated in the South-West part of Ethiopia, between $4^{\circ} 30^{\prime}$ and $9^{\circ} 30^{\prime} \mathrm{N}$ latitude, and between $35^{\circ}$ and $38^{\circ} \mathrm{E}$ longitude (Fig. 1). It flows from the northern highlands through the lowland zone to discharge into Lake Turkana at the Ethiopia and Kenya in the south. It encompasses parts of two National Regional States; Oromia which occupies the north-eastern part of the basin and the rest of the basin, the study area, is situated in the Southern People's Regional States. It is drained by two major rivers; Gibe and Gojeb river. The northern part of the basin has several tributaries which the largest are the Walga and Wabe rivers. The Tuljo and Gilgel Gibe rivers drains to the Gibe (Water Works Design Supervision Enterprise (WWDSE) and South Design and Construction Supervision Enterprise (SDCSE) 2013).

\section{Data collection and processing}

In a given area, the magnitude of soil erosion rate is varied, both temporally and spatially, due to the existing

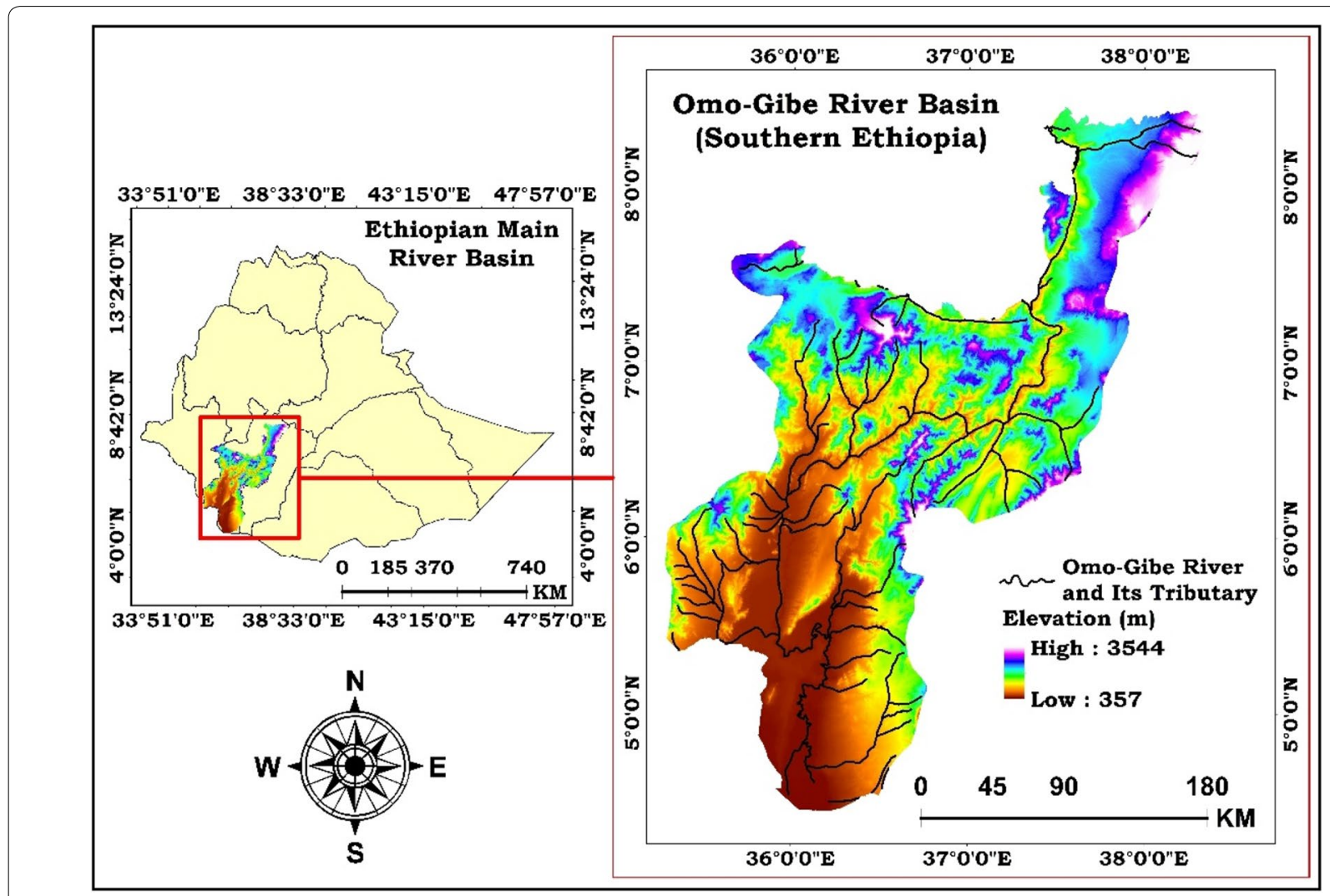

Fig. 1 Boundary of the study area 
local condition mainly biophysical and land management variables (Wischmeier and Smith 1978; Renard et al. 1997 and Morgan 2005). The central idea is-the collection of spatial data is crucial (Lulseged et al. 2017). To this end, the following datasets were collected from different sources and processed using the conventional methods in ArcGIS 10.7.1 environment.

\section{Rainfall-Runoff erosivity factor (R)}

The erosive factor $(\mathrm{R})$, the only climatic parameter in RUSLE, is the numerical measure of the erosive power of rainfall (Wischmeier and Smith, 1978). As Foster et al. (2003) denoted, rainfall amount and intensity are considered the most important rainfall attributes and has greater annual variations too. R-correlation established by Hurni (1985) for Ethiopia (Eq. 1) was adopted to compute R-factor value in ArcGIS raster calculator (Amsalu and Mengaw, 2014; Wolka et al. 2015; Gelagay and Minale, 2016; Gashaw et al. 2018). Where by, $\mathrm{P}$ is the mean annual rainfall in $\mathrm{mm}$ generated from 30 years (1999-2018) rainfall data collected from Ethiopian National Meteorological Agency. Inverse Distance weighted (IDW) method was then implemented to generate the rainfall erosivity $(R)$ value across the river basin and R-factor map was generated as a raster layer (Gizaw and Degifie, 2018).

$$
R=-8.12+(0.562 * P)
$$

\section{Soil erodibility factor (K)}

Soil erodibility (K), the susceptibility of soil towards erosion, is highly dependent on the inherent properties of the soil (Wischmeier and Smith, 1978; McCool et al. 1995). $\mathrm{K}$ is the rate of soil loss per rainfall erosion index (R) for a standard condition of bare soil, recently tilled up-and-down slope with no conservation practice and on a slope of $5^{\circ}$ and $22 \mathrm{~m}$ length (Renard et al. 1997 and Morgan, 2005). Soil map, in vector format, collected from Ethiopian Ministry of Water, Irrigation and Energy (MoWIE) was converted in to raster map using the Feature to Raster tool in ArcGIS. The $\mathrm{K}$ factor value was then estimated based on a formula (Eq. 2) adapted from Williams (1995) as follows in raster calculator (Gezahegn et al. 2018):

$$
K_{\text {RUSLE }}=f_{\text {csand }} \times f_{\text {cl-si }} \times f_{\text {orgC }} \times f_{\text {hisand }}
$$

where $f_{\text {csand }}$ is a factor that gives low soil erodibility factors for soils with high coarse-sand contents and high values for soils with little sand, $f_{c l-s i}$ is a factor that gives low soil erodibility factors for soils with high clay to silt ratios, $f_{\text {orgC }}$ is a factor that reduces soil erodibility for soils with high organic carbon content, and $f_{\text {hisand }}$ is a factor that reduces soil erodibility for soils with extremely high sand contents. The factors are calculated as be (Eq. 3-6) (Neitsch et al. 2002):

$$
\begin{aligned}
& f_{\text {csand }}=\left(0.2+0.3 * \operatorname{Exp}\left[-0.256 * m_{s} *\left(1+\frac{m_{\text {silt }}}{100}\right)\right]\right) \\
& f_{\text {cl-si }}=\left(\frac{m_{\text {silt }}}{m_{c}+m_{\text {silt }}}\right)^{0.3} \\
& f_{\text {orgC }}=\left(1-\frac{0.256 * \operatorname{org} C}{\operatorname{org} C+\operatorname{Exp}[3.72-2.95 * \operatorname{org} C]}\right) \\
& f_{\text {hisand }}=\left(1-\frac{0.7 *\left(1-\frac{m_{s}}{100}\right)}{\left(1-\frac{m_{s}}{100}\right)+\operatorname{Exp}\left[5.51+22.9\left(1-\frac{m_{s}}{100}\right)\right]}\right)
\end{aligned}
$$

where $\mathrm{m}_{\mathrm{s}}$ is the percent sand content $(0.05-2.00 \mathrm{~mm}$ diameter particles), $\mathrm{m}_{\text {silt }}$ is the percent silt content (0.002$0.05 \mathrm{~mm}$ diameter particles), $\mathrm{m}_{\mathrm{c}}$ is the percent clay content ( $<0.002 \mathrm{~mm}$ diameter particles), and orgC is the percent organic carbon content of the layer (\%).

\section{Slope length and steepness factor (LS)}

In a particular are, the effect of topography on soil erosion is represented by its slope length and steepness condition. According to Wischmeier and Smith (1978) and Schmidt et al (2019), considering the two as a single topographic factor, LS, is more convenient. LS was generated using freely available $30 \mathrm{~m} * 30 \mathrm{~m}$ resolution digital elevation model (DEM) from ASTER DEM. L factor was calculated by Eq. 7 using raster calculator (Wischmeier and Smith, 1978; Desmet and Govers, 1996). The equation considers the flow accumulation and adding a ratio of rill to interrill erosion (Schmidt et al, 2019).

$$
L_{i, j}=\frac{\left[\left(A_{i, j-i n}+D^{2}\right)^{m+1}-\left(A_{i, j-i n}\right)^{m+1}\right]}{\left(D^{m+2}\right) \times\left(X_{i, j}^{m}\right) \times(22.13)^{m}}
$$

where $L_{i, j}$ is the slope length factor for grid cell $(i, j), A_{i, j-i n}$ is contributing area (flow accumulation) in $\mathrm{m}^{2}$ at the inlet of grid cell with coordinates (i,j), D is the grid cell size in $\mathrm{m}$ (20 $\mathrm{m}$ in this study).

$\mathrm{X}_{\mathrm{i}, \mathrm{j}}=\sin \alpha_{\mathrm{i} ;}+\cos \alpha_{\mathrm{i}, \mathrm{j}}, \alpha_{\mathrm{i} ; \mathrm{j}}$ is the aspect direction of the grid cell with coordinate (i,j), $m$ is a variable slope-length exponent is related to the ratio $\beta$ of rill and interrill erosion (Fig. 8) and $\beta$-value was calculated by Eq. 9 (McCool et al. 1989).

$$
m=\beta /(\beta+1)
$$




$$
\beta=\left(\frac{\sin \theta}{0.0896}\right) /\left[3(\sin \theta)^{0.8}+0.56\right]
$$

where $\theta$ is the slope angle in degree.

According to McCool et al. (1989), soil loss increases more rapidly with slope steepness than it does with slope length and the slope steepness (S) factor was computed by Eqs. 10 and 11 using raster calculator.

$$
\begin{aligned}
& S=10.8 \sin \theta+0.03 \text { for slope in percent }<9 \% \\
& S=16.8 \sin \theta+0.5 \text { for slope in percent } \geq 9 \%
\end{aligned}
$$

\section{Cover and management factor (C)}

The C-factor represents conditions that can most easily be managed to reduce erosion ( $\mathrm{McCool}$ et al. 1995). For this study, cloud free Landsat 8 Imagery from https:// glovis.usgs.gov of 2018 was attained to classify the LULC on the basis of spectral signatures and terrain characteristics. Prior to classification, image preprocessing was implemented and classification was processed using supervised image classification technique according to the desired decision rule of maximum likelihood algorithm (Abiyot et al. 2018; Suji et al. 2015) using ERDAS IMAGINE 2018. Classification accuracy was assessed by using overall accuracy (OA) and Kappa coefficient (K) based on error matrix. The error or confusion matrix was calculated by comparing the classification results and ground truth data (Hassan et al. 2016). The accuracy was assessed by using 521 reference points. The OA is the total percentage of pixels correctly classified. It was calculated as ratio (Eq. 12) between the number of correctly classified pixels $(a)$ and the total number of pixels (b) used for accuracy assessment (Shao et al. 2016).

$$
O A=\left(\frac{a}{b}\right) \times 100
$$

Kappa test was performed to measure the extent of classification accuracy as it considers all of the elements of the error matrix (Hassan et al. 2016; Bouaziz et al. 2017), was computed as a statistical measure of interrater reliability, was computed as given by Eq. 13 (Shao et al. 2016):

$$
K=\frac{N \cdot \sum_{i}^{r} x_{i i}-\sum\left(x_{i+} \cdot x_{+i}\right)}{N^{2}-\sum\left(x_{i+} \cdot x_{+i}\right)}
$$

where $r$ is the number of rows in the matrix, $x_{i i}$ is the number of observations in row $i$ and column $i, x_{i+}$ and $x_{+i}$ are the marginal totals of the row $i$ and column $i$, respectively, and $N$ is the total number of observations.

Hence, the derived thematic LULC raster map was imported in ArcMap to assign the corresponding
C-factor values adopted from different literatures (Table 4) (Erdogan et al. 2006; Hurni, 1985; Bewket and Teferi, 2009; Tadesse and Abebe, 2014; Abate, 2011; Gelagay and Minale, 2016; Ganasri and Ramesh, 2015; Eweg et al. 1998; Wischmeier and Smith, 1978) and raster map of $\mathrm{C}$-factor was generated.

\section{Support and conservation practices factor (P)}

The erosion control practice factor $(\mathrm{P})$ reflects the effects of measures to reduce the amount and rate of water runoff and thus soil erosion. According to $\mathrm{McCool}$ et al. (1995), the P-factor mainly represents how surface conditions affect flow paths and flow hydraulics. For this study, P-value was adopted from Wischmeier and Smith (1978) where the slope of the area was correlated with the land use types as management activities are highly dependent on slope of the area. It was implemented in Ethiopia by different scholars (Yesuph and Dagnew, 2019; Gelagay and Minale, 2016; Beshir and Awdenegest, 2015; Gizachew, 2015; Gashaw et al. 2018; Tiruneh and Ayalew 2015). Procedurally, the identified LULC and slope in percent of the study area has been reclassified based on the desired range (Table1). The LULC was grouped in to cultivated land and other land uses. The category under "other land uses" were given the P-value of 1 regardless of their slope class whereas the cultivated land was classified into six slope classes. Spatial analyst Boolean-And operation was implemented on the reclassified cell values of the two input raster (LULC and slope) in ArcMap. Then the outputted LULC and slope combinate raster was used to assign the corresponding $p$ values with the help of ArcMap editor tool and P factor value raster map was produced.

\section{Quantitative estimation of soil loss}

Annual soil loss rate was estimated by Eq. 14 superimposing and multiplying the respective preceding RUSLE factor values interactively using Raster Calculator in ArcGIS 10.7.1 (McCool et al. 1995).

Table 1 P-values which were used in the study area

\begin{tabular}{lll}
\hline LULC & Slope (\%) & P-factor \\
\hline Cultivated land & $0-5$ & 0.1 \\
& $5-10$ & 0.12 \\
$10-20$ & 0.14 \\
& $20-30$ & 0.19 \\
$30-50$ & 0.25 \\
Other land & $50-100$ & 0.33 \\
\hline
\end{tabular}




$$
A=R \times K \times L S \times C \times P
$$

where $A$ is the amount of soil erosion $\left(\mathrm{t} \mathrm{ha}^{-1} \mathrm{yr}^{-1}\right), R$ is the rainfall erosivity factor (MJ mm ha $\left.{ }^{-1} \mathrm{~h}^{-1} \mathrm{yr}^{-1}\right), K$ is

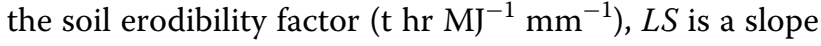
length and steepness factor (dimensionless), $C$ is a cover factor that accounts for the land use and cover (LULC) class (dimensionless), and $P$ is a conservation/management support practice factor (dimensionless).

\section{Creation of soil erosion severity map}

For the purpose of identifying priority areas, soil loss potential of the basin was categorized into six different severity classes as low (0-7 t/ha/yr), moderate (7-15 t/ ha/yr), high (15-25 t/ha/yr), very high (25-45 t/ha/ yr), sever (45-60 t/ha/yr) and very sever (>60 t/ha/yr) (Habtamu and Amare, 2016). Nonetheless, map showing the severity distribution was created for conservation planning.

\section{Results and discussion}

This study was intended to assess the spatial distribution of soil erosion using GIS-RUSLE interface model (Fig. 2). In this regard, each input parameters were derived from different data sources and the results were discussed as follows:

\section{Rainfall erosivity (R-value)}

According to the IDW result (Table 2), the average annual rainfall of the study area ranges

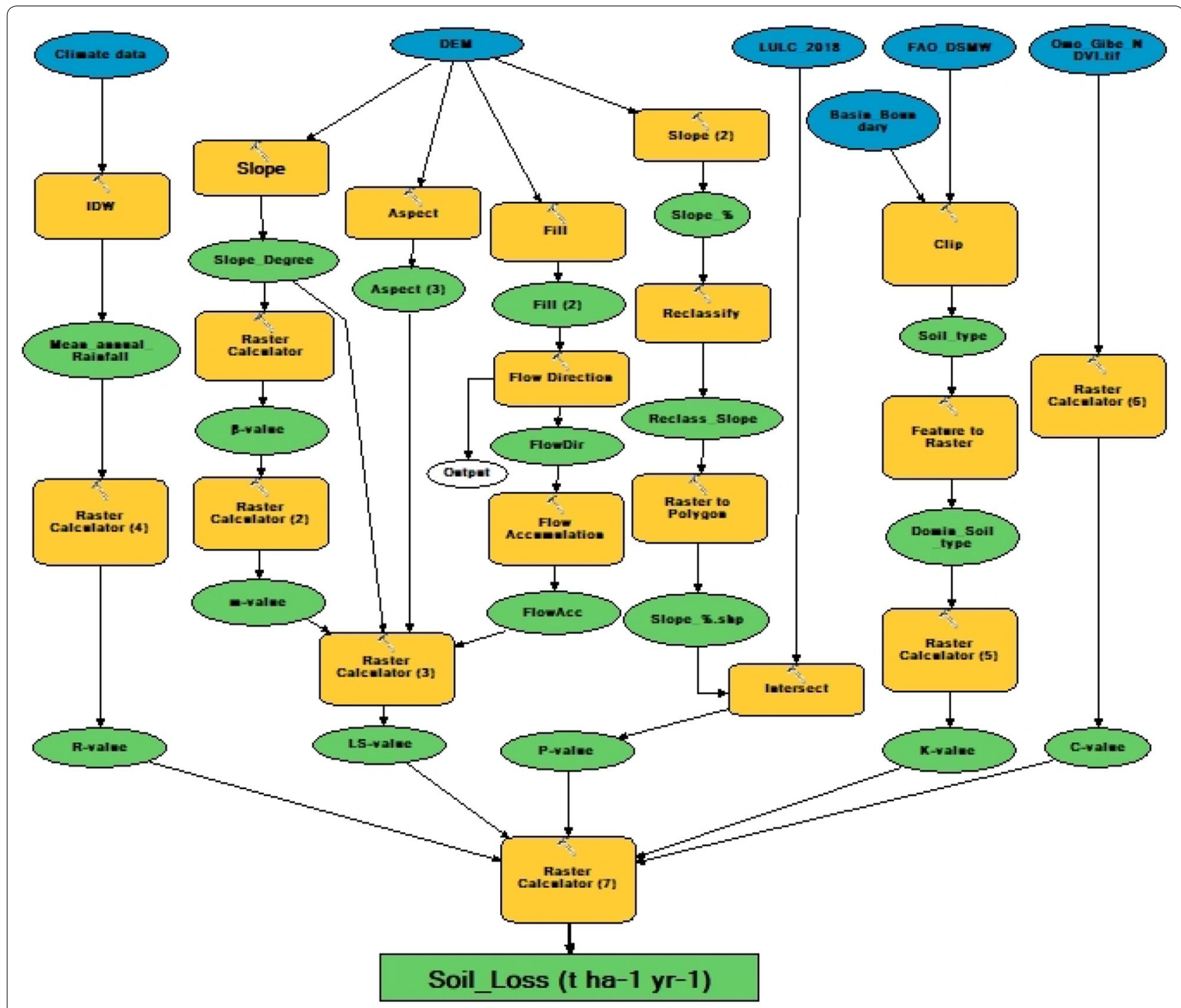

Fig. 2 The GIS-RUSLE interface framework implemented in this study 
Table 2 Mean annual rainfall and $R$ value of each stations

\begin{tabular}{lcl}
\hline Station name & $\begin{array}{l}\text { Mean annual rainfall } \\
(\mathbf{m m})\end{array}$ & $\begin{array}{l}\mathbf{R} \text { value }(\mathbf{M J ~ m m} \\
\mathbf{h a}^{-\mathbf{1}} \mathbf{h}^{\mathbf{- 1}} \mathbf{\mathbf { y r } ^ { - \mathbf { 1 } } \mathbf { ) }}\end{array}$ \\
\hline Wolkite & 1200 & 666 \\
Bele & 836.98 & 462 \\
Chida & 1178 & 654 \\
Dimeka & 545.78 & 299 \\
Hosaena & 1214.9 & 675 \\
Jinka & 1242.7 & 690 \\
Morka & 1104.7 & 613 \\
Turmi & 616.18 & 338 \\
Wolaita & 1200.8 & 667 \\
\hline
\end{tabular}

between 546 and $1243 \mathrm{~mm}$. The R-factor analyzed using Eq. 2 indicated that, the value ranges from 299 to $690 \mathrm{MJ} \mathrm{mm} \mathrm{ha}{ }^{-1} \mathrm{~h}^{-1} \mathrm{yr}^{-1}$ with a mean of $563 \mathrm{MJ} \mathrm{mm} \mathrm{ha}{ }^{-1} \mathrm{~h}^{-1} \mathrm{yr}^{-1}$. The spatial distribution (Fig. 3) confirms that there is a variation of rainfall erosivity value in the entire basin. The upper and central part of the basin is relatively dominated by high R value. A study conducted by Gerawork (2014) on Gibe-III dam catchment (central part of OmoGibe river basin) also revealed the rainfall variability and its potential impact on erosion. At the lower part and near to the basin outlet, $\mathrm{R}$ value accounts for low range (Turmi and Dimeka stations). These trends were mainly reliant on the spatial distribution of the average annual rainfall. Hence, spatio-temporal variations in soil loss are highly connected with variations in the $\mathrm{R}$ factor (Shina et al. 2019) and this revealed the importance of rainfall erosivity to assess erosion hotspot areas.

\section{Soil erodibility (K-value)}

Physico-chemical properties of the soil affect its resistance to detachment and transportation. The $\mathrm{K}$ value in Omo-Gibe river basin ranged from 0 to $0.22 \mathrm{t} \mathrm{hr}$ $\mathrm{MJ}^{-1} \mathrm{~mm}^{-1}$ (Fig. 4). Most of the lower part of the basin was dominated by loamy soil and characterized with high $\mathrm{K}$ value ranging from 0.17 to $0.22 \mathrm{t} \mathrm{hr} \mathrm{MJ}^{-1} \mathrm{~mm}^{-1}$; hence these soils are highly affected by erosion. On the other hand, the upper and central part is more of clay dominant. Clay loam and sandy nature of soil was also found. These soils have a moderate $\mathrm{K}$ value ranging from 0.14 to $0.16 \mathrm{t} \mathrm{hr} \mathrm{MJ}^{-1} \mathrm{~mm}^{-1}$ while low $\mathrm{K}$ value $(<0.14 \mathrm{t} \mathrm{hr}$ $\mathrm{MJ}^{-1} \mathrm{~mm}^{-1}$ ) was observed in the lower border and outlet of the basin that revealed the area more resists the impact of rainfall kinetic energy. In 2019, Melku (2019) and his colleagues were confirmed the central part (Geshy subcatchment) is dominated by clays with slow infiltration rate. Clay and sandy dominated soils have low $\mathrm{K}$ value because of resistant to detachment and high infiltration rates respectively. Silty loam soils have moderate to high $K$ values, as the soil particles are moderately to easily

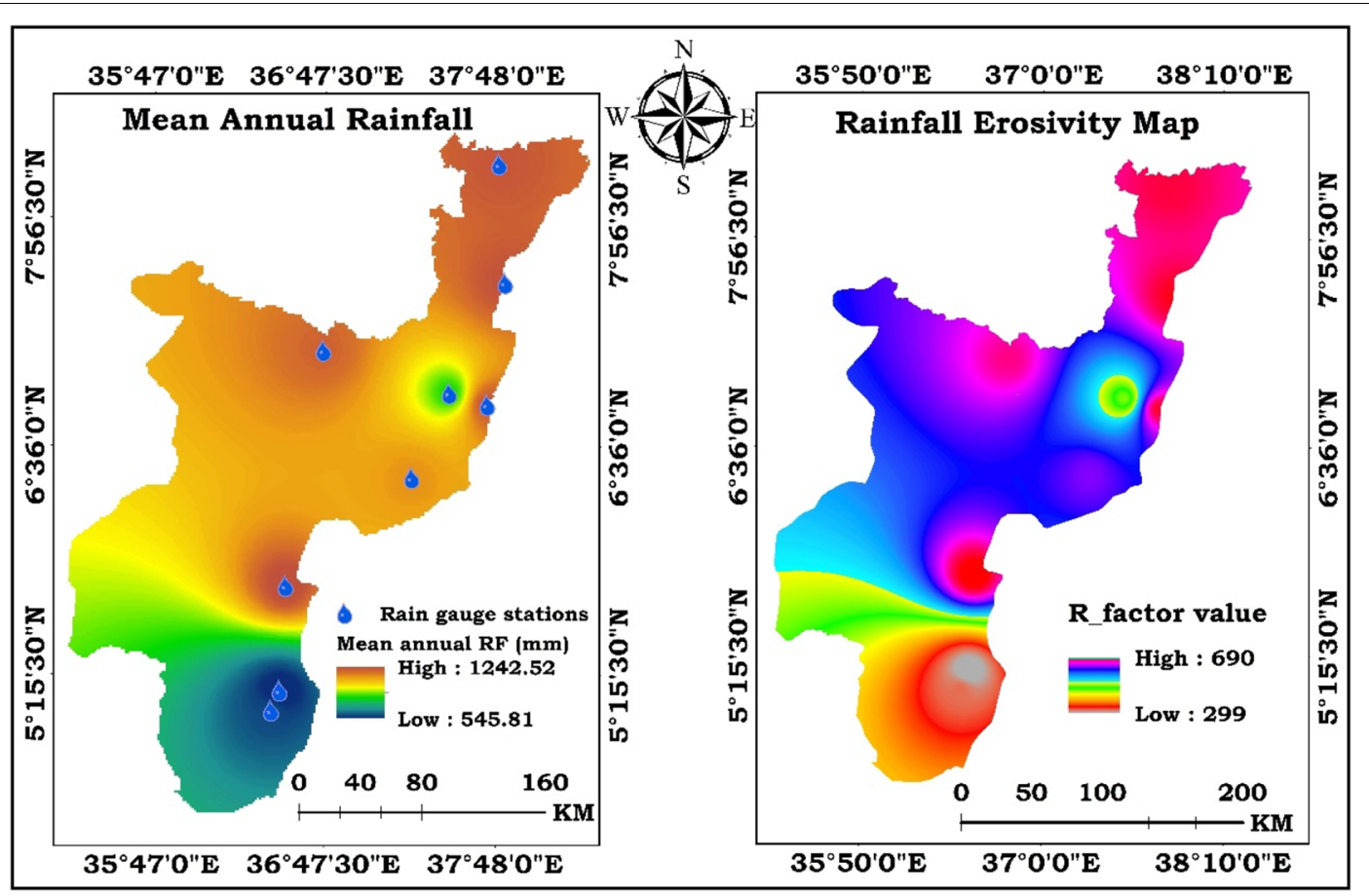

Fig. 3 Mean annual rainfall and R-factor value 


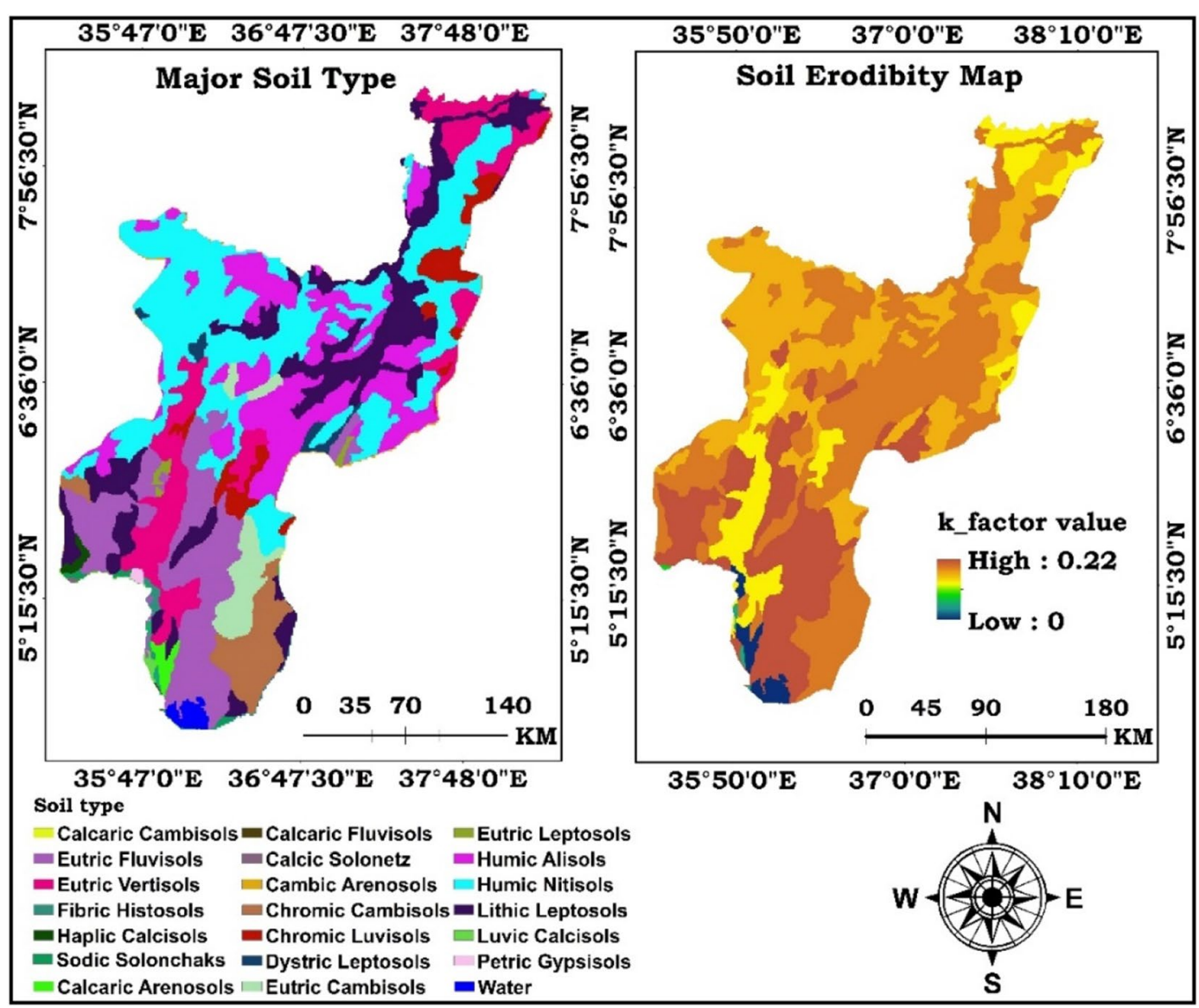

Fig. 4 Major soil type and the computed $K$ factor value

detachable, infiltration is moderate to low (Gizaw and Degifie, 2018). Wall et al (1987), concluded that soils with high infiltration rates, higher levels of $\mathrm{OM}$ and improved structure have a greater resistance to erosion. Nonetheless, soil erosion is a function of many factors. Gizaw and Degifie (2018) calculated the mean K value for central part of the Omo-Gibe basin (Gilgel Gibe-I catchment) as $0.358 \mathrm{t} \mathrm{hr} \mathrm{MJ}^{-1} \mathrm{~mm}^{-1}$.

\section{Topographic (LS-value)}

The slope angle and aspect direction of the study basin is ranging $0-64^{0}$ and -1 to $359.8^{0}$ respectively. The $\beta$-value derived from Eq. 9 is found between 0 and 3.02. The $m$-value is ranging from $0-0.75$. In the central part of the basin, the gradient was characterized with steep slope ranging up to $64^{0}$ (Fig. 5). In the southern part, the area has been dominated by lower elevation and flat slope $\left(<3^{0}\right)$. The combined LS factor varies from 0 in the lower part of the basin to 46.58 in the steepest central and upper part of the basin (Fig. 5). As noted by Shiferaw et al. (2016), steep slopes with dissected hills characterize the highland part while the low lands are characterized by relatively gentle and undulating slopes. Areas with higher LS values are generally located in the steep slope terrain.

\section{Cover and management (C-value)}

Based on the 2018 Landsat image analysis, seven different LULC (Table 3) classes were identified where 54.4\% of the study basin was dominated by cultivated land. Forest cover and grassland was accounted for $16.2 \%$ and $14.8 \%$ respectively. The smallest class was settlement/ built-up area. A study conducted in Gigel Gibe-I catchment (central part of Omo-Gibe) also found the same trends of LULC (Gizaw and Degifie, 2018). The OA (86.94\%) and K statistical test (0.8) conducted using 521 sampled reference observations has been found within the range of the acceptable limits (Anderson et al. 1976) (Table 3). For each LULC types, the corresponding C-values were assigned in Table 4 and Fig. 6 showed the spatial distribution of $\mathrm{C}$ values. Most of the southern part was covered by shrubs and forest cover dominated the north western part of the study basin; hence this part of the basin has assigned lower $C$ value. Though cultivated land 


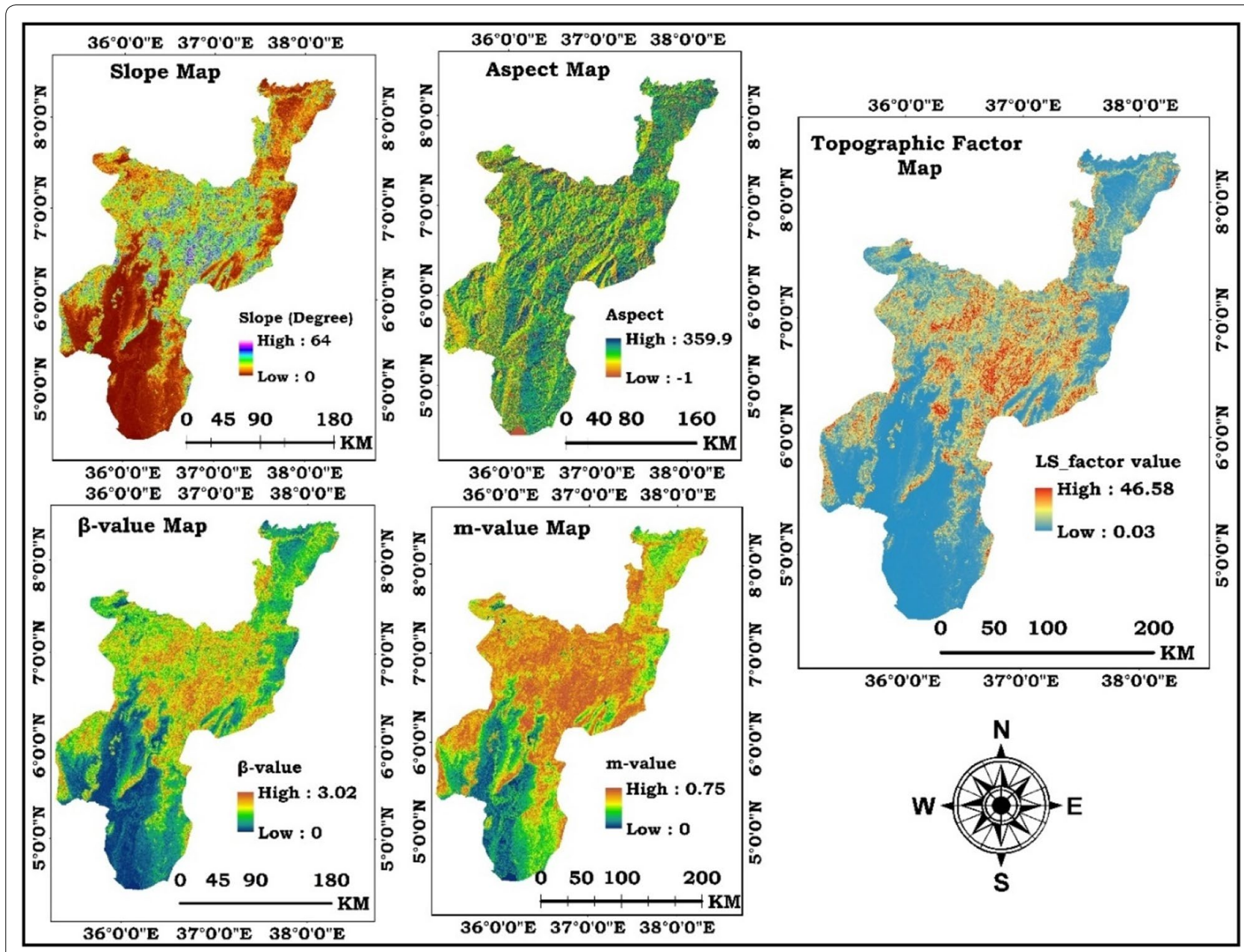

Fig. 5 LS value (E) calculated using slope (A), aspect direction (B), $\beta(C)$ and $m$ value (D)

Table 3 Accuracy Assessment result using confusion matrix

\begin{tabular}{|c|c|c|c|c|c|c|c|c|}
\hline \multirow{2}{*}{ Class data } & \multicolumn{8}{|c|}{ Reference data } \\
\hline & Forest land & Cultivated land & Grass land & Bare land & Built-up area & Water body & Shrub land & Total \\
\hline Forest land & 68 & 2 & 0 & 0 & 0 & 0 & 3 & 73 \\
\hline Cultivated land & 10 & 250 & 4 & 4 & 0 & 0 & 6 & 274 \\
\hline Grass land & 0 & 0 & 64 & 0 & 0 & 0 & 0 & 64 \\
\hline Bare Land & 0 & 0 & 1 & 6 & 5 & 0 & 5 & 17 \\
\hline Built-up area & 3 & 0 & 0 & 0 & 5 & 0 & 0 & 8 \\
\hline Water body & 0 & 0 & 0 & 0 & 0 & 10 & 0 & 10 \\
\hline Shrub land & 0 & 20 & 5 & 0 & 0 & 0 & 50 & 75 \\
\hline Total & 81 & 272 & 74 & 10 & 10 & 10 & 64 & 521 \\
\hline
\end{tabular}

was found in the entire area, mostly dominants the north and north eastern part. So that this part including bare ground was accounted for the highest $C$ value. In such area it is unlikely to reduce the direct impact of rainfall as compared to perennial and forest cover (Gelagay and Minale, 2016). 
Table 4 Land cover classes and assigned cover (C) factor values

\begin{tabular}{llcl}
\hline LULC class & \multicolumn{2}{l}{ Area coverage } & C-factor \\
\cline { 2 - 3 } & ha & \% & \\
\hline Water body & 27,112 & 0.5 & 0 \\
Cultivated land & $3,124,590$ & 54.4 & 0.15 \\
Shrub land & 744,171 & 12.95 & 0.014 \\
Grass land & 850,643 & 14.8 & 0.05 \\
Bare land & 65,524 & 1.1 & 1 \\
Built-up area & 1592 & 0.03 & 0.09 \\
Forest land & 932,778 & 16.2 & 0.01 \\
Total & $5,746,410$ & & \\
\hline
\end{tabular}

\section{Erosion management (P-value)}

The entire LULC was grouped in to cultivated land where further classified into six slope class and given P-values and land uses classified under forest, water body, grass, shrub, bare and built-up were grouped as other land uses given the P-value of 1 . The $\mathrm{P}$ value obtained from the correlation between the slope in percent and LULC of the study area was ranged from 0.1 to 1 . As can be seen in Fig. 7, P value of 1 is observed in the southern and some of the north western central parts of the basin. On the other hand, lower P-value (0.1) is dominant on the upper (north east) part of the basin. The higher the $\mathrm{P}$ value, the more the area is dominated by grass cover and shrub land where erosion management practice were not implemented (Gelagay and Minale, 2016).

\section{Soil loss estimation (A)}

With the help of ArcGIS 10.7.1, the RUSLE input parameters ( $R, K, L S, C$ and $P$ ) were created as a raster layer in a grid format. These thematic layers were then processed in raster calculator tool to generate map that shows the annual soil loss of the study area. The GIS-RUSLE based estimation showed the annual soil loss ranging from 0 in flat terrain to $279 \mathrm{t} \mathrm{ha}^{-1} \mathrm{yr}^{-1}$ in the steep slope central area and extended to the upper part of the basin (Fig. 8). The mean annual soil loss is.

$69 \mathrm{t} \mathrm{ha}^{-1} \mathrm{yr}^{-1}$ and the entire basin losses a total of about $89.6 \mathrm{Mt}$ of soil annually. Compared with the tolerable soil loss limit (TSL), 26\% $(1,494,066.6 \mathrm{ha})$ of the entire basin area is by far higher than the maximum limit (18 $\mathrm{t} \mathrm{ha}^{-1} \mathrm{yr}^{-1}$ ) determined by Hurni (1985). Gizaw and Degifie (2018), reported mean annual soil loss of $62.98 \mathrm{t} \mathrm{ha}^{-1} \mathrm{yr}^{-1}$ in the central part of OmoGibe (Gilgel Gibe-I catchment). For the year 2013, $60.9 \mathrm{t} \mathrm{ha}^{-1} \mathrm{yr}^{-1}$ mean soil loss was recorded in Jimma Zone ranged from 1.6 to $232.4 \mathrm{t} \mathrm{ha}^{-1} \mathrm{yr}^{-1}$ (Beshir and

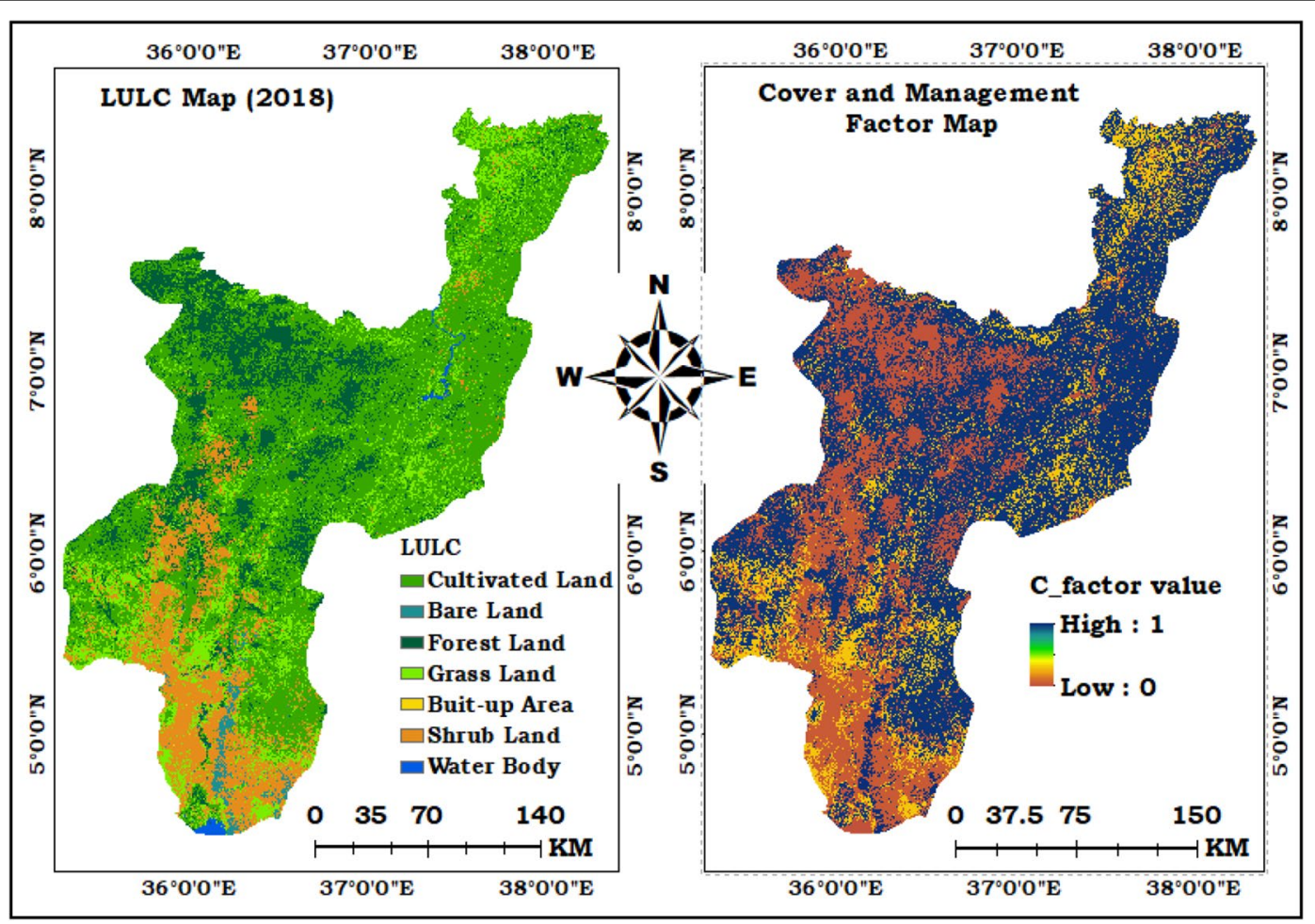

Fig. 6 C factor value (B) map produced from the LULC (A) 


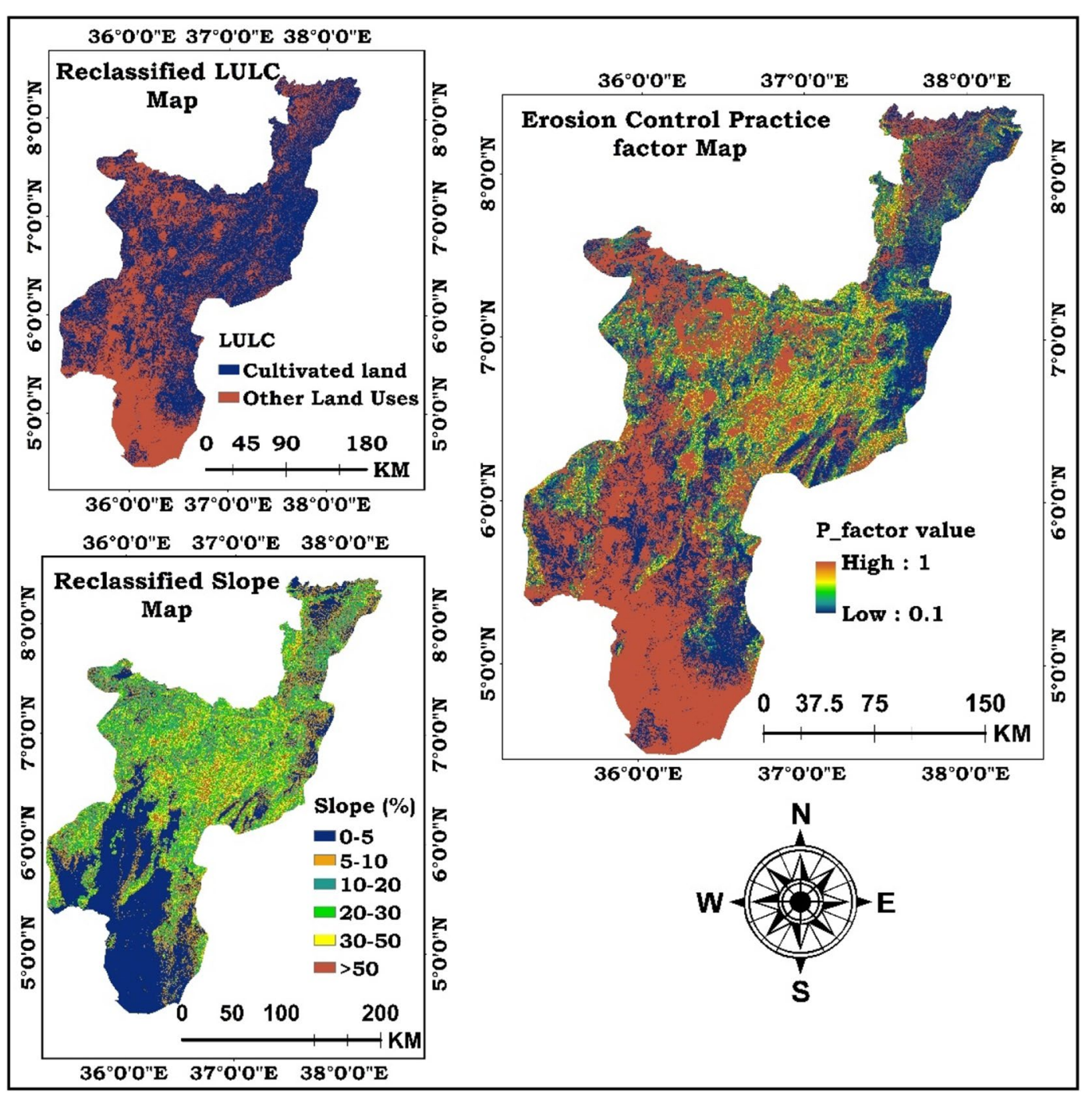

Fig. 7 P factor value (C) produced using reclassified slope and LULC

Awdenegest, 2015). In the Ethiopian highlands, soil erosion ranges from 16-300 $\mathrm{t} \mathrm{ha}^{-1} \mathrm{yr}^{-1}$ (Hurni, 1988). According to Tesfaye and Bogale (2019), high amount of soil loss rate was recorded in the upper catchment of Omo-Gibe river basin (Gilgel Gibe -III watershed) due to deforestation, spares land cover, shallow soil depth and high rainfall intensity. Most of the central parts of the Omo-Gibe river basin is characterized by steeply sloping terrain; hence higher soil loss was estimated in this area. Out of the total soil loss, $44 \%$ (highest amount) was contributed from Weyibe Zigna Zege subbasin where $35 \%$ of its slope exceed $15^{\circ}$ and the lowest amount $(2.9 \%)$ was drown from Hamerkake Omo subbasin where more than $95 \%$ of the sub-basin has a slope lower than $15^{\circ}$.
This denotes there was spatial soil loss variability and the influence of the combined LS factor for soil loss is significant in the central and upper part of Omo-Gibe river basin than the lower part. As noted by Adugna et al. (2015), the amount of soil loss in Ethiopia mainly relay on the degree of slope gradient, characteristics of rainfall intensities and type and/or intensity of land cover. Though there are different factors, several studies were also indicated the impact of LS factor on soil erosion in different part of Ethiopia. According to Gashaw et al. 2018, high soil erosion rate $\left(237 \mathrm{t} \mathrm{ha}^{-1} \mathrm{yr}^{-1}\right)$ was recorded in the hilly terrain of the Geleda watershed, northern Ethiopia. Gezahegn et al. 2018, found a mean annual soil loss of $51.04 \mathrm{t} \mathrm{ha}^{-1} \mathrm{yr}^{-1}$ for the year 2000 in the eastern part of the country. In 2014, Amsalu and 


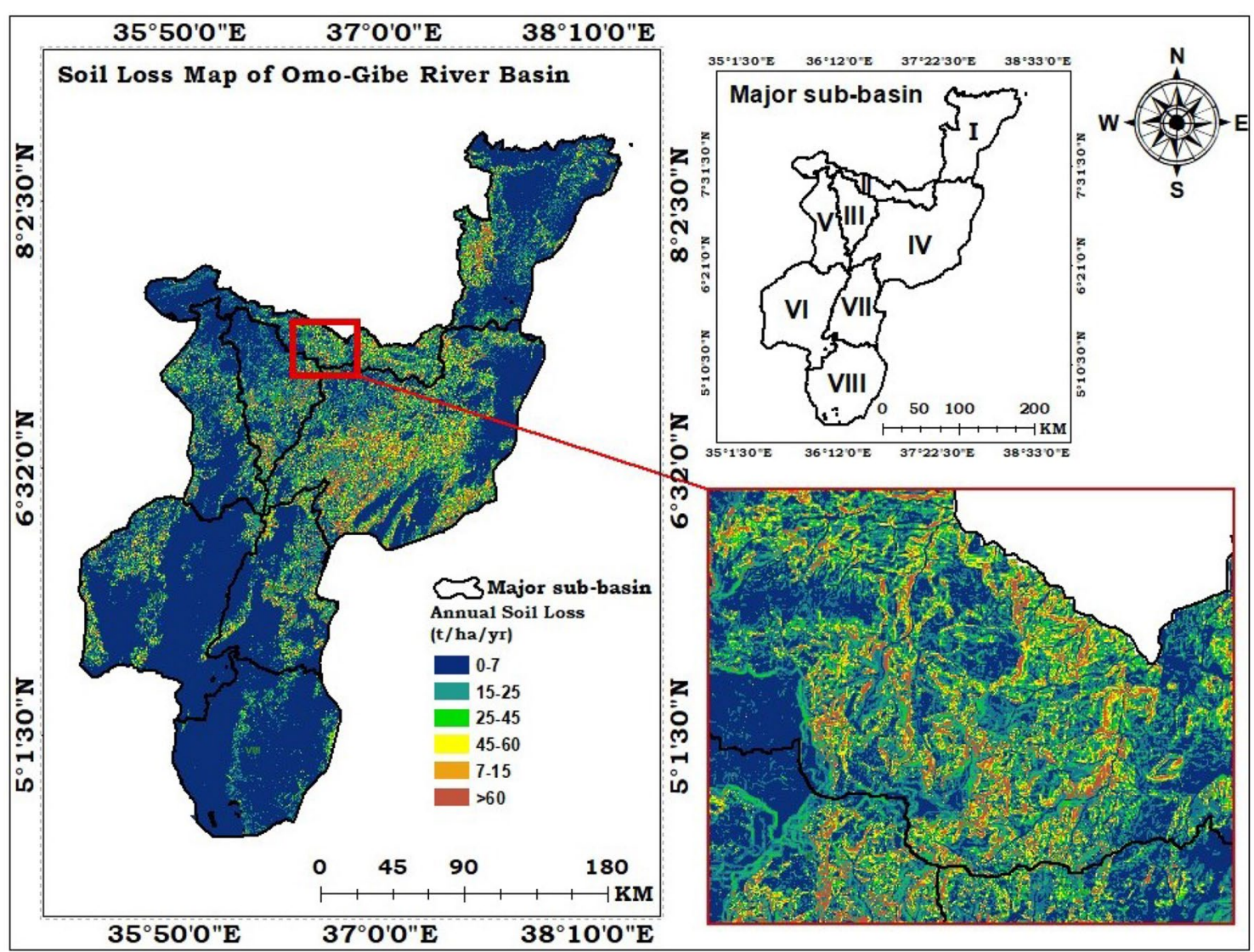

Fig. 8 Spatial distribution soil erosion loss (severity map) in Omo-Gibe river basin

Mengaw also reported an extremely high amount of soil loss (504.6 $\mathrm{t} \mathrm{ha}^{-1} \mathrm{yr}^{-1}$ due to steep terrain) much greater than the soil loss estimation of the Ethiopian highlands. Gebreyesus and Kirubel (2009), observed the highest soil loss from steep slopes in Medego watershed. Generally, the finding of this study is in a good agreement and realistic compared with previous studies.

\section{Prioritization for soil conservation planning}

In limited resource condition, prioritizing erosion hot spot area is important for land managers and policy makers to emphasize on effective planning and implementation of appropriate intervention measures (Gashaw et al. 2018; Lu et al. 2004; Shi et al. 2004 and Haregeweyn et al. 2013). To prioritize for intervention planning, the study area was subdivided into eight major sub-basins and further categorized in to six erosion severity classes (Table 5): about $53.29 \%$ of the area was categorized under low erosion risk which extends from $0-7 \mathrm{t} \mathrm{ha}^{-1} \mathrm{yr}^{-1}$ that contributes $5.5 \%$ of total soil loss; $17.61 \%$ is characterized in moderate class ranging between $7-15 \mathrm{t} \mathrm{ha}^{-1} \mathrm{yr}^{-1}$ and accounted $11.6 \%$ of soil loss; $8.56 \%$ of the area is found in the high erosion risk class $\left(15-25 \mathrm{t} \mathrm{ha}^{-1} \mathrm{yr}^{-1}\right.$ sharing $10.8 \%$ of soil loss); $16.3 \%$ of the annual soil loss was derived from $8.7 \%$ of the entire area which was categorized under very high erosion risk (25-45 $\left.\mathrm{t} \mathrm{ha}^{-1} \mathrm{yr}^{-1}\right)$, while the remaining $4.82 \%$ and $7.01 \%$ area was categorized as sever (45-60 $\mathrm{tha}^{-1} \mathrm{yr}^{-1}$ accounted $16.5 \%$ of total soil loss) and very sever (>60 $\mathrm{tha}^{-1} \mathrm{yr}^{-1}$ where $39.3 \%$ of the total soil loss was contributed from) respectively. As confirmed by several studies (Amare et al. 2014; Gashaw et al. 2018; Abate, 2011), it was observed that small area of the Omo-Gibe basin contributed for the significant amount of soil loss. Areas characterized under very sever erosion risks were given the first priority and the viceversa for soil conservation planning.

\section{Conclusions}

Soil erosion by water is considered as the major cause degradation processes. Understanding the extent and its spatial distribution is essential to make sustainable land management more effective with limited resources especially in developing countries like Ethiopia. The empirical analysis of this study indicated that the mean annual soil loss from the entire area was $69 \mathrm{t} \mathrm{ha}^{-1} \mathrm{yr}^{-1}$ which significantly exceed country's threshold value. 
Table 5 Soil loss rates and severity classes of major sub basins

\begin{tabular}{|c|c|c|c|c|c|c|c|c|}
\hline \multirow{2}{*}{$\begin{array}{l}\text { Sub basin } \\
\text { number }\end{array}$} & \multicolumn{6}{|c|}{ Severity class (t/ha/yr) and area coverage (ha) } & \multirow{2}{*}{$\begin{array}{l}\text { Total soil } \\
\text { loss (Mt } \\
\mathrm{yr}^{-1} \text { ) }\end{array}$} & \multirow[t]{2}{*}{$\%$ of total } \\
\hline & 0-7 (Low) & 7-15 (Moderate) & 15-25 (High) & $\begin{array}{l}\text { 25-45 (Very } \\
\text { high) }\end{array}$ & $45-60$ (Sever) & $>60$ (Very sever) & & \\
\hline । & 376,147 & 146,135 & 57,245 & 64,756 & 22,812 & 40,894 & 10.2 & 11.4 \\
\hline$\|$ & 124,953 & 98,333 & 45,701 & 49,757 & 23,527 & 30,425 & 7.5 & 8.4 \\
\hline III & 107,982 & 112,256 & 51,255 & 34,514 & 17,050 & 28,288 & 7.0 & 7.8 \\
\hline IV & 451,716 & 311,471 & 163,745 & 189,804 & 133,461 & 212,611 & 39.4 & 44.0 \\
\hline V & 232,224 & 122,190 & 44,215 & 38,450 & 22,625 & 20,487 & 6.6 & 7.4 \\
\hline VI & 754,750 & 97,701 & 50,514 & 45,653 & 28,050 & 26,931 & 7.7 & 8.6 \\
\hline VII & 312,049 & 85,535 & 47,791 & 51,493 & 25,535 & 39,797 & 8.6 & 9.6 \\
\hline VIII & 702,465 & 38,368 & 31,665 & 25,619 & 4062 & 3403 & 2.6 & 2.9 \\
\hline Total & $3,062,286$ & $1,011,989$ & 492,131 & 500,046 & 277,122 & 402,836 & 89.6 & - \\
\hline$\%$ Area & 53.29 & 17.61 & 8.56 & 8.70 & 4.82 & 7.01 & - & - \\
\hline Priority & 6th & 5 th & 4 th & $3 r d$ & 2nd & $1 s t$ & - & - \\
\hline
\end{tabular}

I=Gigel Gibe, II=Gojeb, III = Guma Danchiya, IV = Weyibe Zigna Zege, V=Sherma, VI = Muwi Omo, VII = Berso Neri Kako \& VIII = Hamerkake Omo

Though there were several factors, the influence of topographic factor was significant on soil erosion variability. The overall result explicitly revealed that more than half of the area was categorized between low to moderate soil loss range, whereas $26 \%$ was identified as erosion hotspots accounted for high to very sever risk class. It was observed that small area of the Omo-Gibe basin contributed for the significant amount of soil loss. Out of the total soil loss, $44 \%$ (highest amount) was contributed from Weyibe Zigna Zege sub-basin where 35\% of its slope exceed $15^{\circ}$. As a result, urgency should be given to those erosion prone areas for watershed management planning and implementation. Further studies should also be conducted to understand the major causes of soil erosion in the study basin.

\section{Abbreviations}

DEM: Digital elevation model; GIS: Geographic information system; IDW: Inverse distance weighted; LULC: Land use land cover; RUSLE: Revised universal soil loss equation; TSL: Tolerable soil loss.

\section{Acknowledgements}

Authors would like to acknowledge the academic staffs from the Faculty of Biosystems and Water Resource Engineering, Institute of Technology, Hawassa university for provision of technical support.

\section{Authors' contributions}

Both authors made a valuable and unreserved contribution. RG wrote the methodology used, carried out the data analysis process, RUSLE model running and wrote the manuscript; EG more engaged on the spatial data collection, LULC classification process and accuracy assessment. Both authors read and approved the final manuscript.

\section{Funding}

This study received no external funding.

\section{Availability of data and materials}

The datasets used and/or analyzed during the current study are available from the corresponding author on reasonable request.
Ethics approval and consent to participate

Not applicable.

Consent for publication

Authors agreed to submit the manuscript for publication in Environmental Systems Research.

\section{Competing interests}

The authors declare that they have no competing interests.

\section{Author details}

${ }_{1}^{1}$ Department of Sustainable Landscape Development, Institute for Geosciences and Geography, Martin Luther University Halle-Wittenberg, Halle, Germany. ${ }^{2}$ Department of Land Administration and Surveying, Wondo Genet College of Forestry and Natural Resources, Hawassa University, Hawassa, Ethiopia.

Received: 14 December 2019 Accepted: 11 August 2020

Published online: 18 August 2020

\section{References}

Abate S (2011) Estimating soil loss rates for soil conservation planning in the Borena woreda of South Wollo highlands. Ethiopia J Sustain Dev Afr 13(3):87-106

Abiyot L, Misikir B, Dereje L (2018) Impacts of community based watershed management on land use/cover change at Elemo micro-watershed, Southern Ethiopia. Am J Environ Protect 6(3):59-67. https://doi. org/10.12691/env-6-3-2

Adugna A, Abegaz A, Cerdà A (2015) Soil erosion assessment and control in Northeast Wollega, Ethiopia. Solid Earth Discuss 7:3511-3540. https://doi. org/10.5194/sed-7-3511-2015

Adugna T, Saathoff F, Seleshi Y, Gebissa A (2013) Evaluating the effectiveness of best management practices in Gilgel Gibe Basin watershed-Ethiopia. J Eng Arch 7(10):1240-1252

Aiello A, Adamo M, Canora F (2015) Remote sensing and GIS to assess soil erosion with RUSLE3D and USPED at River Basin Scale in Southern Italy. CATENA 131:174-185. https://doi.org/10.1016/j.catena.2015.04.003

Alexandridis TK, Sotiropoulou AM, Bilas G, Karapetsas N, Silleos NG (2015) The effects of seasonality in estimating the $\mathrm{C}$-factor of soil Erosion studies. Land Degrad Dev 26:596-603. https://doi.org/10.1002/ldr.2223

Amare S, Nega C, Zenebe G, Goitom T, Alemayoh T (2014) Landscape-scale soil erosion modeling and risk mapping of mountainous areas in eastern escarpment of Wondo Genet watershed, Ethiopia. Int Res J Agric Sci Soil Sci 4(6):107-116 
Amsalu T, Mengaw A (2014) GIS based soil loss estimation using RUSLE model: the case of Jabi Tehinan Woreda, ANRS, Ethiopia. Nat Res 5:616-626. https ://doi.org/10.4236/nr.2014.511054

Anderson JR, Hardy EE, Roach JT, Witmer RE (1976) A Land-Use and LandCover Classification System for Use with Remote Sensor Data. US Geological Survey Professional Paper 964, Washington.

Balabathina V, Raju RP, Mulualem W (2019) Integrated remote sensing and gis-based universal soil loss equation for soil erosion estimation in the Megech River Catchment, Tana Lake Sub-basin, North-western Ethiopia. Am J Geogr Inf Syst 8(4):141-157

Belayneh M, Yirgu T, Tsegaye D (2019) Potential soil erosion estimation and area prioritization for better conservation planning in Gumara watershed using RUSLE and GIS techniques. Environ Syst Res 8:20. https://doi. org/10.1186/s40068-019-0149-x

Beshir K, Awdenegest M (2015) Identification of soil erosion hotspots in Jimma Zone, Ethiopia, using GIS based approach. ET J Environ Stud Manage 8(Suppl. 2):926-938. https://doi.org/10.4314/ejesm.v8i2.7S

Bewket W, Teferi E (2009) Assessment of soil erosion hazard and prioritization for treatment at the watershed level: case study in the Chemoga watershed, Blue Nile basin, Ethiopia. Land Degrad Dev 20:609-622

Bouaziz M, Eisold S, Guermazi E (2017) (2017) Semiautomatic approach for land cover classification: a remote sensing study for arid climate in southeastern Tunisia. Euro-Mediterr J Environ Integr 2:24. https://doi. org/10.1007/s41207-017-0036-7

Desmet PJJ, Govers G (1996) A GIS procedure for automatically calculating the USLE LS factor on topographically complex landscape units. J Soil Water Conserv 51:427-433

Erdogan E, Erpul G, Bayramin I (2006) Use of USLE/GIS methodology for predicting soil loss in a semiarid agricultural watershed. Environ Monit Assess 131:153-161

Eweg HPA, Van Lammeren R, Deurloo H, Woldu Z (1998) Analysing degradation and rehabilitation for sustainable land management in the highlands of Ethiopia. Land Degrad Dev 9(529):542

Fazzini M, Bisci C, Billi P (2015) The climate of Ethiopia. In: Billi P (ed) Landscapes and landforms of Ethiopia. World geomorphologic landscapes. Springer, Dordrecht, pp 65-87

Fernandez C, Wu J, McCool D, Stockle C (2003) Estimating water erosion and sediment yield with GIS, RUSLE, and SEDD. J Soil Water Consery 58(3):128-136

Foster IDL, Chapman AS, Hodgkinson RM, Jones AR, Lees JA, Turner SE, Scott M (2003) Changing suspended sediment and particulate phosphorus loads and pathways in undertrained lowland agricultural catchments; Herefordshire and Worcestershire, U.K. In: Kronvang B (ed) The interactions between sediments and water. Developments in hydrobiology, vol 169. Springer, Dordrecht, pp 119-126 10.1007/978-94-017-3366-3_17

Ganasri BP, Ramesh H (2015) Assessment of soil erosion by RUSLE model using remote sensing and GIS - a case study of Nethravathi Basin. Geosci Front. https://doi.org/10.1016/j.gsf.2015.10.007

Gashaw T, Taffa T, Mekuria A (2017) Erosion risk assessment for prioritization of conservation measures in Geleda watershed Blue Nile basin, Ethiopia. Environ Syst Res. https://doi.org/10.1186/s40068-016-0078-x

Gashaw T, Tulu T, Argaw M (2018) Erosion risk assessment for prioritization of conservation measures in Geleda watershed, Blue Nile basin, Ethiopia. Environ Syst Res 6:1. https://doi.org/10.1186/s40068-016-0078-x

Gebreyesus B, Kirubel M (2009) Estimating soil loss using universal soil loss equation (USLE) for soil conservation planning at Medego watershed Northern Ethiopia. J Am Sci 5(1):58-69

Gelagay HS, Minale AS (2016) Soil loss estimation using GIS and remote sensing techniques: a case of Koga watershed international soil and water conservation research Northwestern Ethiopia. Int Soil Water Conserv Res. $4(2): 126-136$

Gerawork B (2014) Spatial erosion hazard assessment for proper intervention: the case of Gibe-III dam catchment, southwest Ethiopia (Masters Thesis, Haramaya University, Ethiopia)

Gezahegn WW, Anteneh DI, Solomon T, Ramireddy UR (2018) Spatial modeling of soil erosion risk and its implication for conservation planning: the case of the Gobele watershed, East Hararghe Zone, Ethiopia. Land 7(1):25

Gizachew A (2015) A geographic information system based soil loss and sediment estimation in Zingin watershed for conservation planning highlands of Ethiopia. IJSTS 3(1):28-35. https://doi.org/10.11648/j.ijsts 20150301.14
Gizaw T, Degifie T (2018) Soil erosion modeling using GIS based RUSEL model in Gilgel Gibe-1 catchment, South West Ethiopia. Int J Environ Sci Nat Res 15(5):555923. https://doi.org/10.19080/IJESNR.2018.15.555923

Habtamu SG, Amare SM (2016) Soil loss estimation using GIS and remote sensing techniques: a case of Koga watershed, Northwestern Ethiopia. Int Soil Water Conserv Res. 4(2):126-136

Haregeweyn N, Poesen J, Govers G, Verstraeten G, de Vente J, Nyssen J, Deckers S, Moeyersons J (2013) Evaluation and adaptation of a spatiallydistributed erosion and sediment yield model in Northern Ethiopia. Land Degrad Dev 24:188-204

Hassan Z, Shabbir R, Ahmad SS, Malik AH, Aziz N, Amna B, Erum S (2016) Dynamics of land use and land cover change (LULCC) using geospatial techniques: a case study of Islamabad Pakistan. SpringerPlus. https://doi. org/10.1186/s40064-016-2414-z

Hurni H (1985) Erosion-Productivity-Conservation systems in Ethiopia. Proceedings of 4 th international conference on soil conservation, Maracay Venezuela, 3-9 November. pp. 654-674

Hurni $\mathrm{H}$ (1988) Degradation and conservation of the resources in the Ethiopian Highlands. Mt Res Dev 8:123-130

Lu D, Li G, Valladares GS, Batistella M (2004) Mapping soil erosion risk in Rondonia, Brazilian Amazonia: using RUSLE, remote sensing and GIS. Land Degrad Dev 15(5):499-512

Lulseged T, Zenebe A, Ermias A, Tesfaye Y (2017) Estimating landscape susceptibility to soil erosion using a GIS-based approach in Northern Ethiopia. Int Soil Water Conserv Res 5:221-230. https://doi.org/10.1016/j.iswcr 2017.05.002

McCool DC, Foster GR, Renard K G, Yoder DC, Weesies GA (1995) The Revised Universal Soil Loss Equation. Department of Defense/Interagency Workshop on Technologies to Address Soil Erosion on Department of Defense Lands San Antonio, TX, June 11-15, 1995

McCool DK, Foster GR, Mutchler CK, Meyer LD (1989) Revised slope length factor for the universal soil loss equation. Trans ASAE 32:1571-1576

Melku D, Awdenegest M, Asfaw KK (2019) Effects of land uses on soil quality indicators: the case of Geshy Subcatchment, Gojeb River Catchment, Ethiopia. Appl Environ Soil Sci. https://doi.org/10.1155/2019/2306019

Meshesha DTs, Tsunekawa A, Tsubo M, Haregeweyn N (2012) Dynamics and hotspots of soil erosion and management scenarios of the Central Rift Valley of Ethiopia. Int J Sedim Res 27:84-99

Morgan RPC (2005) Soil erosion and conservation, 3rd edn. Hoboken, Blackwell Publishing company

Neitsch SL et al (2002) Soil and water assessment tool (SWAT) user's manual, version 2000, Grassland Soil and Water Research Laboratory. Blackland Research Center, Texas Agricultural Experiment Station, Texas Water Resources Institute, Texas Water Resources Institute, College Station, Texas

Panditharathne DLD, Abeysingha NS, Nirmanee KGS, Mallawatantri A (2019) Application of revised universal soil loss equation (RUSLE) model to assess soil erosion in "Kalu Ganga" River Basin in Sri Lanka. Appl Environ Soil Sci. https://doi.org/10.1155/2019/4037379

Phinzi K, Ngetar NS (2019) The Assessment of water-borne erosion at catchment level using GIS-based RUSLE and remote sensing: a review. Int Soil Water Conserv Res 7:27-46. https://doi.org/10.1016/j.iswcr.2018.12.002

Popp JH, Hyatt DE, Hoag D (2000) Modeling environmental condition with indices: a case study of sustainability and soil resources. Ecol Model 130:131-143

Renard KG, Foster GR, Weesies GA, McCool DK, Yoder DC (1997) Predicting soil erosion by water: a guide to conservation planning with the revised universal soil loss equation (RUSLE). USDA, Agriculture Handbook No 703, Washington

Schmidt S, Tresch S, Meusburgere K (2019) Modification of the RUSLE slope length and steepness factor (LS-factor) based on rainfall experiments at steep alpine grasslands. MethodsX 6:219-229. https://doi.org/10.1016/j. mex.2019.01.004

Shao Z, Fu H, Fu P, Yin L (2016) Mapping urban impervious surface by fusing optical and SAR data at the decision level. Remote Sens 8:945. https://doi. org/10.3390/rs8110945

Shi ZH, Cai SF, Ding SW, Wang TW, Chow TL (2004) Soil conservation planning at the small watershed level using RUSLE with GIS: a case study in the Three Gorge Area of China. CATENA 55(1):33-48. https://doi.org/10.1016/ S0341-8162(03)00088-2

Shiferaw B, Okello J, Reddy VR (2009) Challenges of adoption and adaptation of land and water management options in smallholder agriculture: 
synthesis of lessons and experiences. In: Wani SP, Rockstron J, Oweis TY (eds) Rain feed agriculture: unlocking the potential. CAB International, London, pp 258-275

Shiferaw EC, Adane A, Santosh MP ( 2016) Assessment of the impact of climate change on surface hydrological processes using SWAT: a case study of Omo-Gibe River Basin. ET Model Earth Syst Environ 2:205. https://doi. org/10.1007/s40808-016-0257-9

Shina JY, Kim T, Heo JH, Lee JH (2019) Spatial and temporal variations in rainfall erosivity and erosivity density in South Korea. CATENA 176(2019):125144. https://doi.org/10.1016/j.catena.2019.01.005

Suji VR, Sheeja RV, Karuppasamy S (2015) Prioritization using morphometric analysis and land use/land cover parameters for vazhichal watershed using remote sensing and GIS techniques. Int J Innov Res Sci Technol 2(1):2349-6010

Tadesse A, Abebe M (2014) GIS based soil loss estimation using RUSLE model: the case of Jabi Tehinan Woreda ANRS, and Ethiopia. Nat Res 5:616-626

Tesfaye A (2015) GIS-based time series assessment of soil erosion risk using RUSLE model: a case study of Cheraqe watershed, Bilate river sub-basin. Unpublished MSc Thesis, Addis Ababa University, Addis Ababa

Tesfaye HE, Bogale G (2019) Bogale G (2019) Modeling-impact of Land Use/ Cover Change on Sediment Yield (Case Study on Omo-gibe Basin, Gilgel Gibe III Watershed, Ethiopia). Am J Mod Energy 5(6):84-93. https://doi. org/10.11648/j.ajme.20190506.11

Tiruneh G, Ayalew M (2015) Soil loss estimation using geographic information system in Enfraz watershed for soil conservation planning in highlands of Ethiopia. Int J Agril Res Innov Tech 5(2):21-30 (ISSN: 2224-0616)

Wall G, Baldwin CS, Shelton IJ (1987) Soil Erosion-causes and effect. Ontario Ministry of Agriculture and Food Fact sheet Agdex \#572, Canada
Water Works Design Supervision Enterprise (WWDSE) and South Design and Construction Supervision Enterprise (SDCSE) (2013) Kuraz Sugar Development Project Sectoral Study Reports: Climatology and Hydrology Study Report

Williams JR (1995) Chapter 25. The EPIC model. In computer models of watershed hydrology. Water Resources Publications, Highlands Ranch, pp 909-1000

Wischmeier WH, Smith DD (1978) Predicting rainfall erosion losses-a guide to conservation planning. U.S Department of Agriculture, Agriculture Handbook No 537, Washington

Wolka K, Tadesse H, Garedew E, Yimer F (2015) Soil erosion risk assessment in the Chaleleka wetland watershed, Central Rift Valley of Ethiopia. Environ Syst Res 4:5. https://doi.org/10.1186/s40068-015-0030-5

Yesuph AY, Dagnew AB (2019) Soil Erosion mapping and severity analysis based on RUSLE model and local perception in the Beshillo catchment of the Blue Nile Basin, Ethiopia. Environ Sys Res. https://doi.org/10.1186/ s40068-019-0145-1

Zhou Q, Yang S, Zhao C, Cai M, Ya L (2014) A soil erosion assessment of the upper mekong river in Yunnan Province, China. Mt Res Dev 34:36-47

Zhou W, Wu B (2008) Assessment of soil erosion and sediment delivery ratio using remote sensing and GIS: a case study of upstream Chaobaihe River catchment, north China. Int J Sedim Res 23:167-173

\section{Publisher's Note}

Springer Nature remains neutral with regard to jurisdictional claims in published maps and institutional affiliations.

\section{Submit your manuscript to a SpringerOpen ${ }^{\odot}$ journal and benefit from:}

- Convenient online submission

- Rigorous peer review

- Open access: articles freely available online

- High visibility within the field

- Retaining the copyright to your article

Submit your next manuscript at $\boldsymbol{\nabla}$ springeropen.com 